University of Wollongong

Research Online

Faculty of Arts, Social Sciences and Humanities

- Papers

Faculty of Arts, Social Sciences \& Humanities

$21-5-2021$

A thanatopolitical visualisation of accounting history: Giorgio Agamben and Nazi Germany

Erin Twyford

University of Wollongong

Follow this and additional works at: https://ro.uow.edu.au/asshpapers

Research Online is the open access institutional repository for the University of Wollongong. For further information contact the UOW Library: research-pubs@uow.edu.au 


\title{
A thanatopolitical visualisation of accounting history: Giorgio Agamben and Nazi Germany
}

\author{
Abstract \\ The extensive measures taken to destroy a people are facilitated by a complex matrix of interrelated \\ actors and practices, yet there remains an underdeveloped implication of accounting in the wider moral \\ and political imperatives. The purpose of this article is to introduce a thanatopolitical visualisation of \\ accounting history adapted from the work of Giorgio Agamben and Michel Foucault. The theoretical \\ triptych implicates business and accounting in the State-sanctioned financial, political and actual deaths \\ of people. Through reference to Nazi Germany (1933-1945) and the companies Deutsche Bank and Ford \\ Werke, the utility of the theoretical device is illustrated, and silences in accounting are given exposure \\ through alternative accounts. Adopting a close-reading method, the peripheral yet integral role of \\ accounting helped conceal the human cost of thanatopolitical ideology. Beyond the Holocaust example, \\ this triptych is relevant for the exploration of other instances of thanatopolitics, such as war, natural \\ disasters and pandemics.

\section{Publication Details} \\ Twyford, E. (2021). A thanatopolitical visualisation of accounting history: Giorgio Agamben and Nazi \\ Germany. Accounting History, Online First, 1-23.
}




\section{Introduction}

Explaining the destruction of people "is a daunting task empirically and even more so theoretically, so much so that some have argued...that it is "inexplicable'" (Goldhagen 1996, p.5). This is due, in part, to the extensive measures that are taken to destroy a people, as facilitated by a complex matrix of organisations, institutions, ideologies, policies and practices. Examples of historical genocide, such as the Holocaust, can therefore be studied from a variety of theoretical perspectives that contribute to new ways of knowing or understanding, particularly where historical artefacts are still being uncovered. From a business and accounting perspective there are still underdeveloped, or unacknowledged, impacts of the wider moral and political implications of calculative practices. While there have been several accounting studies of the period covering Nazi Germany (see Funnell 1998; Walker 2000; Lippman and Wilson 2007), 'inexplicability' remains. The purpose of this study is to situate the historical events of the Holocaust within a potentially fruitful new theoretical framework based on Giorgio Agamben's (1995, 2002, 2005) critical social theory, informed by Michel Foucault's $(1976,1978,1979)$ lectures on biopolitics, to enrich our understanding of the ways in which a politics that is fixated on death (thanatopolitics) can lead to losses of life in financial, political and existential ways. 
A thanatopolitical visualisation of accounting history: Giorgio Agamben and Nazi Germany.

Agamben focuses on the political systems that enable the internment of citizens within a state of exception - a place of legalised lawlessness on the fringes of civil society borne from a state of emergency. Using specific terms to distinguish between those within the state of exception (zoè, a 'bare' life) and those who remain in the state (zoē with the addition of bios - a 'political' life), Agamben situates his work within Foucault's theory of biopolitics, or a politics predicated on augmenting and endorsing the life of certain citizens. Foucault's work can be given new insight through Agamben's notions of the state of exception, zoe and bios, together with the view that individuals have financial lives as shaped by a series of transactions, and are essentially "economic men[sic]" (Roethlisberger \& Dickson 1939; Miller \& O’Leary 1987; Bhimani 1994). Agamben and Foucault deemphasise financial 'life', which serves to deproblematise the role of accounting in wider socio-political and legal spheres. To address this gap, the paper introduces to Agamben's zoē and political bios a third form of life which can be disciplined, measured and revoked by the State - financial bios. Financial bios is necessary since political bios excludes a financial life, and without highlighting the financial, we risk its disappearance into the political, and subsequent abandonment. By drawing attention to a financial bios, the oft-neglected financial persecution of citizens and its consequences are emphasised. To include financial bios within Agamben's thanatopolitics, the study introduces the triptych as a methodological framework. The 
A thanatopolitical visualisation of accounting history: Giorgio Agamben and Nazi Germany.

triptych provides a tripartite understanding of State/citizen relations to appreciate how State ideology is mediated through business and calculative practices. The paper presents the Holocaust as a relevant example of thanatopolitics that resonates with other historical and contemporary practices, such as detention and refugee camps, civil wars, pandemics and natural disasters.

The period represented as the Holocaust has already gained the attention of accounting scholars. Dillard (2003) reconstructs Black's (2001) account of IBM's alignment of organisational control with destructive Nazi bureaucracy. Booth et al. (2007) unmask the 'dark side' of organisational culture in the Nazi era with reference to a German publishing company, Bertelsmann, and its nuanced support of the Nazi regime. Walker's (2000) investigation into the 1938 Fifth International Congress on Accounting held in Berlin led him to argue that accountants became integral to the Nazi State as the vehicle for the implementation of 'economic order' through Nazi ideology. Detzen and Hoffmann (2020) highlight the pervasiveness of Nazi doctrine on academics within a German university during the war years, and how accountability benchmarks became aligned with Nazi ideology. Though Funnell (1998), Lippman and Wilson (2007) and authors of more general business histories such as Billstein et al. (2000), James (2001) and Hayes (2004) acknowledge the widespread complicity of business owners and managers and other professionals in the Holocaust, the accounting literature pays 
A thanatopolitical visualisation of accounting history: Giorgio Agamben and Nazi Germany.

scant attention to the role of businesses in Aryanisations, slave labour, and the genocide of the Jews. There remains significant scope to undertake theoretically informed research, utilising the framework offered by this paper, to unmask and demystify the role of business and accounting in facilitating citizen death, particularly in financial, political and physical senses.

This paper adopts a broad view of accounting, to encompass the giving and receiving of financial accounts which have moral, ethical and hermeneutical implications (Arrington and Francis 1993, p.108). Accounting, as a translation device, ensures that citizen's lives are writ in accounting discourse. The accounting that this paper is interested in goes beyond "practices and institutions of a professionalised elite" (Arrington and Francis 1993, p.107) to include a range of calculative practices such as measuring, counting and enumerations. In these representations, the human element is negated by accounting, devaluing and rendering invisible lived experiences. What was unaccounted for, either through silences or integers that masked the human element of transactions and events, require alternative accounts that re-situate the human experience as worthy of inclusion and value.

Historical research relies on fragmented sources of evidence, therefore this study draws on numerous sources, including annual reports, financial statements, business histories, particularly that of James (2001) and Billstein et al. (2000), legislation, 
A thanatopolitical visualisation of accounting history: Giorgio Agamben and Nazi Germany.

testimony, speeches and court documents to demonstrate the theoretical triptych. Utilising a close-reading method (cf. Amernic and Craig 2017) that which was unaccounted for in the business records of prominent German war time companies, including Deutsche Bank and Ford Werke, is considered. Companies instrumentalised Nazi ideology as 'strategic centres' to operationalise the loss of financial and political bios through State-directed transactions, using accounting to "supplant the qualitative dimensions of the Jews as individuals by commodifying and dehumanising them, and, thereby, for all intents to make them invisible as people" (Funnell 1998, p.439). Alternative accounts as a form of testimony (Agamben 2002) are deployed to consider the three-fold process and effects of an ideology based in thanatopolitics, to give greater dimension to the numbers (Vollmer 2007).

The paper is organised as follows. The next section outlines the gaps in current theory that Agamben's work could meet within critical accounting history. Following this, an explication of the theoretical framework and triptych is given. Next, methodological reflections are provided. The theoretical triptych is then applied to the context of Nazi Germany to demonstrate its utility, using illustrative examples from businesses deployed under the Nazi State agenda: Deutsche Bank and Ford Werke. The paper closes by providing an overview of the mobilisation of Agamben, and offers 
A thanatopolitical visualisation of accounting history: Giorgio Agamben and Nazi Germany.

suggestions for future historical and contemporary research using the theoretical triptych.

\section{Biopolitics and Agamben in accounting research}

Accounting history research has seen a "substantial expansion and maturation of its research agenda" (Fleischman and Radcliffe 2005, p.61), in which research moved from a traditionalist approach of 'retelling history' to a 'new' (critical) approach that views historical events from various theoretical perspectives. The theoretical framework presented in this paper reflects a 'new' approach of Foucauldian influence, and aligns with the critical approach that seeks deeper knowledge of accounting in its social and political contexts (Vollmer 2007). While Foucault has been used to examine the notions of discipline and power (see, for example, Miller and O'Leary 1987; Miller 1990; Bigoni and Funnell 2015), and governmentality (see, for instance, Neu 2000; Sargiacomo et al. 2016); Maran et al. (2016) argue that it is biopolitics that holds the most potential for questions concerning the how of power that seeks to know, govern and control the citizenry.

In terms of $20^{\text {th }}$ century socio-political conditions, Foucault's thoughts moved from sovereign power, or the State imperative to make die and let live certain members of the citizenry, to biopower. Biopower relates to actions of the State that support some 
A thanatopolitical visualisation of accounting history: Giorgio Agamben and Nazi Germany.

citizens (that is, make live) and reject others (let die). Foucault (1976) conceives that with the logic of biopower, 'undesirable' elements of the population are allowed to die, and the superior group is made to proliferate. Foucault's work on biopolitics has emerged in the critical accounting literature (see, for example, Thorne 2009; Martinez 2011; Cooper 2015; Cooper et al. 2016; Himick 2016; Alawattage et al. 2018), but there is a notable gap in the extension of biopolitics to State/citizen relations. Critical accounting researchers have only just begun to unpack Foucault's concept of biopolitics and apply it in the context of accounting, which this study develops with reference to the work of Agamben, a novel approach in the critical accounting literature.

Agamben's work has been used widely by scholars of law (Fogel 2014; Rigi 2012), politics (McGovern 2011; McLoughlin 2016; Snoek and Fry 2015; Xenofontos 2016), human rights (Adams and Erevelles 2017; Gray and Porter 2015; Lueck et al. 2015) and organisation studies (Marti and Fernandez 2013; Quattrone 2006; Stokes and Gabriel 2010). Agamben's work has been largely overlooked by the accounting literature, with the exceptions of Huber and Scheytt (2013), who analyse the state of exception in the context of risk management during a financial crisis, and Sargiacomo et al. (2015), who briefly mention his state of exception in the aftermath of natural disasters. Given the role that accounting plays within society and in deployments of power (Miller 1990; Miller and Rose 1990), Agamben's conceptualisations have the potential to enrich 
A thanatopolitical visualisation of accounting history: Giorgio Agamben and Nazi Germany.

research in this domain, especially that concerned with accounting in the management of ( financial) lives.

Agamben's work has informed the theoretical triptych introduced in this paper, which can be used to implicate the role of accounting in State pursuit of thanatopolitics. It reveals how a loss of financial life is one of three major ways the State subjects citizens to death. Agamben pays attention to the power apparatuses that enable loss of life, and the inextricable links between law, politics and economics. Using this theoretical device, genocide can be deconstructed as the last horror of a systematic process of eradicating citizen wealth, stripping away political identity, and only then killing people.

\section{A novel theoretical framework: Agamben's critical theory}

Agamben's conceptualisation of thanatopower is underpinned by Foucauldian notions of biopower and modern racism, along with concepts relevant to the operation of sovereign power. Thanatopower takes on both the active 'make live' element of biopower and the active 'make die' component of sovereign power, offering a 'make live and make die' dual imperative. Thanatopower drives thanatopolitics, which plays out in three stages of death: financial, political and physical. Agamben's theorisations offer a means of gaining greater insight into the thanatopolitical agenda by examining the interrelationships between businesses, the State and the citizenry. While 
A thanatopolitical visualisation of accounting history: Giorgio Agamben and Nazi Germany.

highlighting the theoretical utility of this framework, Agamben, like other theorists, is not without his critics (see, for example, Howell and Richter-Montpetit 2019; LaCapra 2007; Mayer 1997; Passavant 2007). The study, however, ascribes to Miller and O'Leary's (1987, p.237) justification in employing a theorist where it is felt "that there is something distinctive in such an approach which is useful in an attempt to understand accounting as a social and organisational practice". To unpack his theorisations, an understanding of Agamben's concepts of forms of life and the state of exception are of fundamental importance.

\subsection{Forms of life}

While Foucault focussed on the biopolitical imperative as it concerned whole populations, Agamben narrowed his attention to the individual. Agamben views individuals within the population as comprising two different elements: the zoe and the bios. He notes that:

...the Greeks had no single term to express what we mean by the word 'life.' They used two terms that....are semantically and morphologically distinct: $z o \bar{e}$, which expressed the simple fact of living common to all living beings (animals, men or gods), and bios, which indicated the form or way of living proper to an individual or group (1995, p.1, emphasis added) 
A thanatopolitical visualisation of accounting history: Giorgio Agamben and Nazi Germany.

It is important to note that Agamben's delineation of forms of life serves to both separate humans from all living things, and to partition humans into two jurisdictions, with potentially devastating consequences.

Zoe is the most basic form of life common to both humans and animals, concerned with survival and reproduction. Its historical absence from the political realm allowed for the 'let live' facet of sovereign power to operate for centuries, until the rapid development of technology and associated biological imperatives of the $20^{\text {th }}$ century politicised bare life and zoe "entered into the sphere of the polis" (Agamben 1995, p.4). Zoē, which was conceptually non-political, the life of "fungible anonymous bodies" (Bazzicalupo 2006, p.115), became an object of State interest. Caught within the realm of the polis, zoē does not participate politically, yet ironically, "no life, as exiles and bandits know well, is more 'political' than [this]" (Agamben 1995, p.184).

With only zoē, whole populations may become subject to the will of the State as a potentially legally sanctioned object of exile, violence or death. When existence is reduced to a bare life, every right bestowed that differentiates humans from other living organisms is stripped by the State, effectively 'killing' without committing homicide (Agamben 1995). Opportunities for genocide then emerge, reflected as a loss of zoē. The ability to kill whole populations, coupled with technologies capable of mass murder and action at a distance, yielded Arendt's horrific and yet plausible conjecture that: 
one fine day a highly organised and mechanised humanity will conclude quite democratically namely by majority decision - that for humanity as a whole it would be better to liquidate certain parts thereof (1973, p.91).

Bios refers to the uniquely human ability to participate politically, be present in the political arena, and have a right to political existence. Bios refers to the right to have rights (Arendt 1973, p.91). This is not to state that bios protects the citizen from violence by the State, as rights are also "the instruments that the sovereign uses for imposing [its] own domination" (Esposito 2013, p.363), and once revoked, the zoē is exposed to State derived impediments to survival and reproduction.

Lost bios results in lost liberty and personal freedoms, exemplified through the practice of forced and slave labouri, and internment within concentration camps in Nazi Germany. The active encouragement of forced and slave labour in German corporations, perceived as cheap and good for business, disregarded the violence, degrading treatment and starvation that the workers were exposed to. The human side of forced and slave labour was largely discounted by not only the guards at the camps, but also the managers and executives of businesses who employed "unpaid workers earmarked for destruction" (Ferencz 2009, p.xxv). The loss of bios removed the personal freedom and liberty of non-Aryans and forced workers by infringing on previously held rights. Accounting condensed the cost of labour and associated costs of labour (for example, rations, clothing and so on.), into one-dimensional metrics, but survivor testimony 
A thanatopolitical visualisation of accounting history: Giorgio Agamben and Nazi Germany.

discloses the conditions of the camp, the violence endured, and the lasting trauma of lost bios.

The singularity of bios neglects the financial self, which is central to State/citizen relations. At this point, the paper adds the notion of financial life (financial bios) to recognise a more nuanced understanding of Agamben's bios, now distinguished as political bios. Llewelyn $(2003$, p.672) recognises the value of such refinements or innovation in what she calls "level three concept theories", particularly in the exploration of practical developments in the world. Giddens $(1987$, p.43) concurs, suggesting that:

...conceptualisation innovation (coupled to empirical research) is at least as important in social science as is the formulating of novel generalisations. For such innovation opens up 'ways of seeing' that do not exist within the perspectives of lay actors, disclosing unsuspected aspects of, and potentialities within, a given set of institutions.

From a theoretical standpoint, Foucault understood the primacy of the economic realm, incorporating his thoughts on power within both the political and economic sphere. His unfinished thesis on biopower and tendency to level his gaze at 'population level' fails to engage at the individual level of bios in economic terms. Foucault did not progress to financial bios, nor move beyond a biopolitical conceptualisation of power. Alternatively, Agamben posits the law as the pre-eminent force in society, and examines the interrelationships between politics and law in deployments of power, but in doing 
A thanatopolitical visualisation of accounting history: Giorgio Agamben and Nazi Germany.

so neglects the economic and financial lives of citizens as they become subordinate, or subsumed, by the law. A gap exists between the two, and this is addressed by the introduction of financial bios.

Financial bios requires differentiation from political bios, as each bios refer to distinctly different modes of 'living proper' (Agamben 1995). Citizen identity is often couched in terms of their labour, or possession of capital and property. Situating our place in the world, we do not often refer to our intrinsic values or political action. This is essentially beyond societal expectation ${ }^{\text {ii }}$. Our sense of identity is instead shaped by a series of transactions that cheapen our identity to 'economic men[sic]' (Arendt 1964; Bhimani 1994; Miller and O'Leary 1987). To bring the notion of political bios back to its Aristotelian origins ${ }^{\mathrm{iii}}$, the paper situates financial life as a means to a political life, rather than modernity's reversal of this process (Arendt 1964). To achieve this, the financial is highlighted, rather than immersed into the political, so the impact of financial persecution on citizens and the role(s) of accounting can be acknowledged.

Citizens have financial lives (Bay 2018; Martins 2002) and the dominant mode of understanding people's financial lives is accounting. Accounting, as a translation device, ensures that citizen's lives are writ in accounting discourse. Financial accounts are given between people daily, in the form of budgets for the household, value of commodities, cost of utilities etc. This often-mundane expression of an individual's life is frequently 
A thanatopolitical visualisation of accounting history: Giorgio Agamben and Nazi Germany.

discounted in other social, political and legal theories. It is, therefore, unsurprising that major theorists such as Agamben have been disinterested in the veiled power of accounting. Accounting operates surreptitiously, but nonetheless imparts human (re)presentation in accounting terms, as the 'indispensable' and unifying language of economics (Lavoie 1987, p.602). Accounting can then become a tool (weapon) apt for use by a State, mediated through business, in implementing its policies. Accounting is intimately linked to the exercise of State power (Miller 1986, 1990) in that it is used as a technique by the State to operationalise its abstract political objectives (Hopwood 1984, 1986; Miller 1990). Thus, accounting, as part of the private sphere of citizens, delivers and enforces State directives, which can make live, or make die, financial bios.

The addition of financial bios recognises the pervasive and concealed role of accounting in facilitating State/citizen relations. Understood as "a process of attributing financial values and rationales to a wide range of social practices" (Miller 1990, p.316), accounting can confer specific visibilities, calculability and operational utility (Burchell et al. 1985; Miller 1990; Miller and O'Leary 1987). Broadbent (1995, p.4) argues that by “making certain aspects of reality 'visible' [accounting] creates the possibility of controlling these elements. It is this partiality in representation and its control potential which constitutes its real social influence, as well as its social danger". Accordingly, accounting can make (in)visible by creating numerated 'silences' which can obscure the 
A thanatopolitical visualisation of accounting history: Giorgio Agamben and Nazi Germany.

social, moral, ethical and ultimately human elements. The perpetuation of such silences requires exposure, which this study undertakes in its examination of financial bios by giving extra dimension to 'numbers' through the integration of context and participants (Vollmer 2007).

The role that financial death plays in political and physical death provides scope to explore the power of accounting in initiating and concealing that death. Distinction between the zoe, political bios and financial bios becomes vital during the operation of thanatopower, as those without financial bios are placed within a separate space - the state of exception - where they are then subjected to further losses including a loss of political bios and a loss of zoē (actual life).

\subsection{State of exception}

The state of exception is "the extension of the military authority's wartime powers into the civil sphere, and...a suspension of the constitution (or of those constitutional norms that protect individual liberties)" (Agamben 2005, p.5). It is "an ambiguous, uncertain, borderline fringe, at the intersection of the legal and the political" (Fontana 1999, p.16), or, in other words, a "legal form of what cannot have legal form" (Agamben 2005, p.1). The state of exception becomes activated when a crisis or 
A thanatopolitical visualisation of accounting history: Giorgio Agamben and Nazi Germany.

emergency occurs that threatens the life of the nation and, as a concept, is historically endorsed by constitutions and international human rights treaties (Humphreys 2006, pp.679-680). The state of exception has been mobilised historically and globally by a number of States in varying instances of emergency ${ }^{\text {iv }}$. Agamben (2005, pp.86-87) argues that a state of exception obliterates the normative quality of law and condones "with impunity...a governmental violence that - while ignoring international law externally and producing a permanent state of exception internally - nevertheless still claims to be applying the law".

Over the course of the last century, 'legal civil war' increasingly entered the political sphere, enabling the state of exception to be an accepted mode of operation in a crisis. As Erlenbusch (2013, pp.49-50) explains, "the exception is not so much an exception as the becoming obvious of a usually hidden mechanism of politics". The state of exception inevitably becomes the rule (Benjamin 1942; Agamben 2005; Huber \& Scheytt 2013), transforming from that exceptional measure to a technique of government that exercises a perpetual exercise of (realised or potential) violence over citizens (Agamben 2005, pp.6-7). This places citizens in a form of purgatory, with rights suspended and without possibility of leaving the state of exception unless the State permits, leaving the potential for a citizen to be reclassified as zoe. 
A thanatopolitical visualisation of accounting history: Giorgio Agamben and Nazi Germany.

The demarcation between who will be designated bare life within the state of exception and stripped of financial and political bios is predicated on Foucault's concept of modern racism, operationalised through State ideology. Modern racism, distinguished as racism directed internally toward the State's own citizens, created enemies which became the impetus for a power mechanism that maintained the State's power while endorsing the policies of the State, such that the State could "scarcely function without becoming involved with racism at some point" (Foucault 1976, p.74).

Modern racism was exemplified in the Nazi State, where race became pseudoscientifically extended to groups such as Jews and Roma. Foucault conceded that "the word 'race' itself is not pinned to a stable biological meaning" (1976, p.77), instead offering that:

we can say that two races exist when there are two groups which, although they coexist, have not become mixed because of the differences, dissymmetries, and barriers created by privileges, customs and rights, the distribution of wealth, or the way in which power is exercised (1976, p.77).

Modern racism sanctions the actions of the State, which by any other name would be persecution, war, murder or massacre. Given these conditions, Foucault outlines, "the most murderous of States are also, of necessity, the most racist" (1976, p.77). 
A thanatopolitical visualisation of accounting history: Giorgio Agamben and Nazi Germany.

Nazism demonstrates the tight, insistent biological regulation that underpins a racist State and allows for the division of a citizenry into zoē and bios, the civil sphere and the state of exception. The state of emergency declaration in Nazi Germany came swiftly after Hitler's appointment as Chancellor in January 1933. An arson attack on the Reichstag, allegedly by political enemies, provided Hitler and the Nazis with the state of emergency that justified the enactment of a series of laws and policies that would fundamentally reshape the German political, social and historical landscape (Goldhagen 1996). The first of these laws was the Reichstag Fire Decree (1933), which suspended the German constitution and "swept away precious civil liberties at a stroke" (Newton 1990, p.191). The decree set out in Article 1 that:

Sections 114, 115, 117, 118, 123, 124, and 153 of the Constitution of the German Reich are suspended until further notice. Therefore, restrictions on personal liberty, on the right of free expression of opinion, including freedom of the press, on the right of assembly and the right of association, and violations of the privacy of postal, telegraphic, and telephonic communications, warrants for house searches, orders for confiscations, as well as restrictions on property, are also permissible beyond the legal limits otherwise prescribed (Decree of the Reich President for the Protection of the People and the State February 28 1933).

Following this, the Enabling Act (1933) authorised Hitler's supreme executive power, sanctioning the enaction of what would become a 12-year state of exception (Newton 1990, p.194). What underlined the ideology and political strategy of the Nazis was antiSemitism, as a form of modern racism, where "without anti-Semitism, Nazism would 
A thanatopolitical visualisation of accounting history: Giorgio Agamben and Nazi Germany.

have been inconceivable, both as an ideology and as a catalyst of the emotions" (Grunberger 1971, p.466). The Nazi State sought to re-establish the Aryan ideal, where citizens would conform to the State's notion of Germanic heritage based mainly on physical attributes and religion. The State particularly separated the Jewish population, adopting an active and aggressive campaign of racist propaganda and legislation, in an attempt to remove Jewish influence from Nazi Germany. This policy, predicated on thanatopower, had the corollary of promoting and advancing the Aryan ideal and endorsing the citizens who possessed the 'correct' biological heritage. The result was internal biological warfare, and indiscriminate killings of Jews, justified and carried out by the State for the good of the State and certain citizens.

The Nazi regime called for the total transformation of society and the economic system, resulting in an inverted capitalist model, where private companies became complicit actors in anti-Semitic policies directed by the State. This economic inversion saw the State implement autarky ${ }^{\vee}$ while transforming private initiatives, business goals and property into ideological directives sought by the State through the implementation of Gleichschaltung. Bullock (1952, p.245) describes Gleichschaltung as a process by which "the whole of the organised life of the nation was to be brought under the single control of the Nazi party". The far-reaching influence of the new government was articulated by the Minister of Economy Walther Funk, who stated that industrial groups 
A thanatopolitical visualisation of accounting history: Giorgio Agamben and Nazi Germany.

and businesses "should accomplish, in addition to their own affairs, all those tasks which the national government imposes upon them" (cited in Matz 1940, p.178). What followed during the next six years, leading up to the outbreak of World War II, was a total change in German life. The National Socialist regime "brought an abrupt aboutface in political, cultural, social, economic and professional thinking in Germany. No phase of national life has remained untouched" (Matz 1938, p.392). Under Gleichschaltung, "the firm was then seen not only as an instrument for attaining private ends, but also as part of a broader context of collective goals" (Cinquini 2007, p.220). In carrying out the thanatopolitical imperatives, the regime worked closely with businesses such as the Deutsche Bank (James 2001), Ford Werke (Billstein et al. 2000), Degussa (Hayes 2004), Krupp (James 2012; Newton 1990), Siemens (Newton 1990), Volkswagen (Mommsen 1996), Daimler-Benz (Hamburg Foundation for Social History 1987) and IG Farben (Hayes 1987). Businesses became strategic centres which operationalised the loss of financial and political bios, impacting the lives of non-Aryan citizens even to the point of death.

\section{Methodological Reflections}

There are many obstacles to obtaining Holocaust data. Access is a major impediment, in that many financial records are not publicly available under German 
A thanatopolitical visualisation of accounting history: Giorgio Agamben and Nazi Germany.

Federal Republic law that restricts access to archives for eighty years (James 2001, p.8). As such, some data from the Nazi period is legally inaccessible. Additionally, many documents were destroyed towards the end of war in the attempt to hide business complicity in the Holocaust (Hayes 2004) and "... [some] companies today still refuse to open their wartime archives, especially to potentially critical historians" (Billstein et al 2000, p.136). Access to company's archival data requires permission, translation and physical presence in the archives. Examining other Holocaust accounting literature makes it evident that other researchers have encountered similar data obstacles. Funnell's (1998) work relied on histories written primarily by Browning (1980), Arad et al (1981), Hilberg (1983), Goldhagen (1996) and Bauman (2001). Dillard (2003) relied on Black's (2001) business history of IBM for his research on accounting systems and the Holocaust, while Lippman \& Wilson (2007) used data from pre-existing texts, such as income statements from Kogon (2006).

Given its theoretical and conceptual emphasis, this study also relies on the histories written by scholars who were given access to the archives of businesses during the Nazi period. The method adopted is based on a close-reading (Amernic \& Craig 2017) of business histories that accessed primary historical archival material of Deutsche Bank and Ford Werke. Given the fragmentary nature of historical evidence, these business histories are supplemented with testimony, legislation, court documents and annual 
reports from the time and about the time, so "documents from diverse sources can 'talk to each other'" (Dean 2008, pp.6-7) and contribute to that rich story concerning the role of accounting in the Holocaust. Essentially, this close-reading or 'teasing-out' consisted of re-reading texts:

that can be seen to hold more 'meaning' than that which has infiltrated the dominant discourse(s) of accounting... It is a search for the 'textual unconscious', or that which is partial but always active in any text and it is part of the struggle to reveal the narrow discursive space in which certain discussion is validated, acceptable and visible, whilst exposing the violence perpetrated against multiple discourses that do not conform to the standards that set the parameters of debate (Andrew 1999, pp.48-49).

Since this documentary evidence was not presented as an accounting story, there was the scope to determine the narrow discursive space as described by Andrew (1999).

The role of accounting in thanatopolitical imperatives remains invisible, and despite its position on the periphery of the wider matrix that operationalises thanatopower, accounting still holds powerful effects that we do not recognise, or see, because we have not had the theoretical tools to do so. Agamben gives us such tools, and the triptych mobilises his work into an empirical device to enable the interrogation of texts and artefacts as a means to make visible that which was concealed, as assisted by accounting (see Diagram 1).

[Insert Diagram 1 here] 


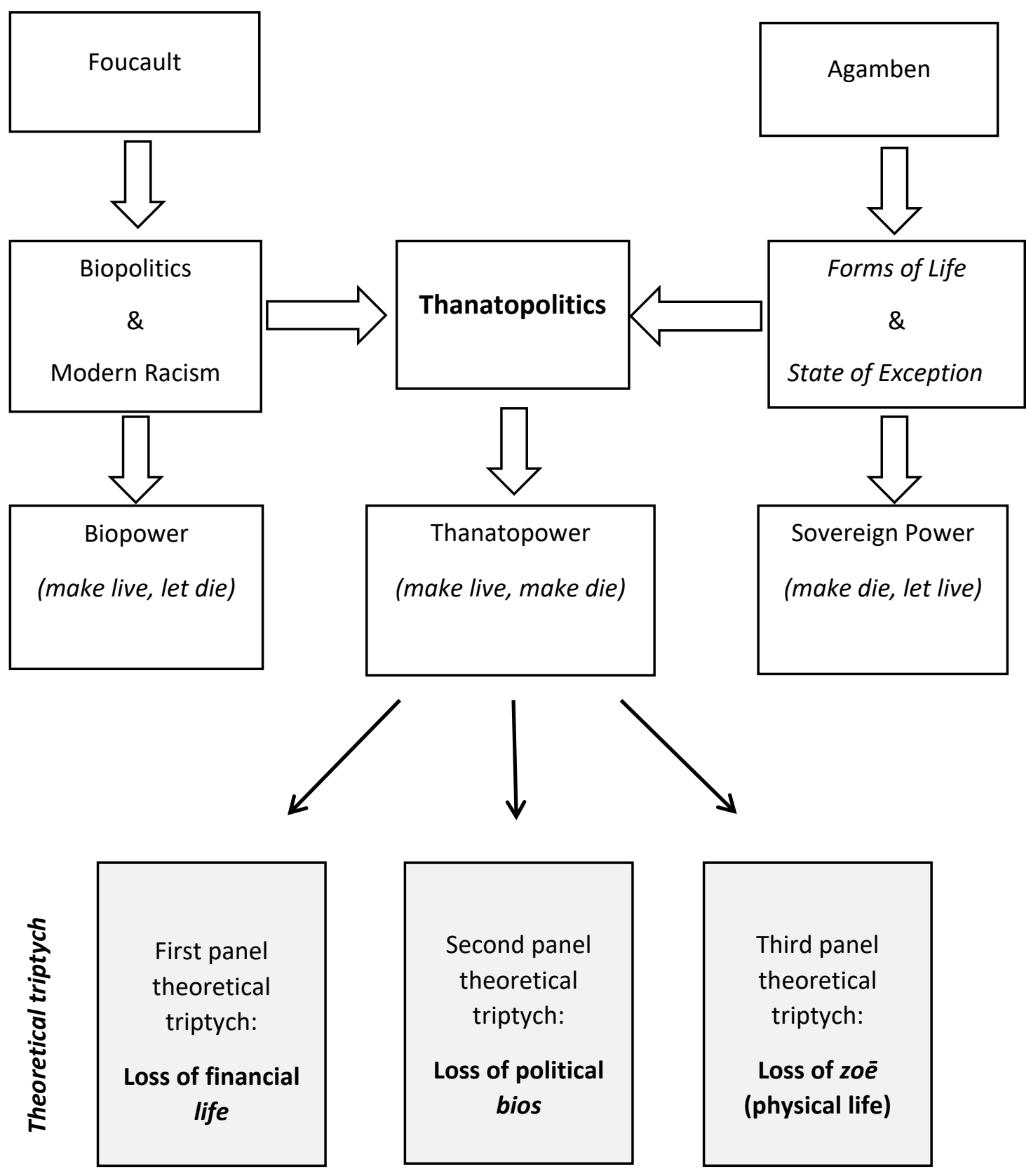

Diagram 1 Theoretical framework 
The origins of thanatopolitical thinking stem from Foucault's biopolitics and modern racism, and Agamben's forms of life and state of exception, as depicted in the top section of the diagram. This is further elucidated by the triptych, in which each panel is explored in turn. The first panel explores the loss of financial bios, which has significant scope for examination through an accounting lens. The business history of Deutsche Bank, in conjunction with their publicly available annual reports (Annual Reports, 19331944), was examined to unveil how what was unaccounted for, namely transactions, people and figures related to Aryanisation, allowed the company to hide its connections to this process. As a corollary, the extent of the human ramifications of the financial persecution was largely hidden by euphemism and special accounts that absorbed Aryanisation related activities.

The second panel, which focusses on the German subsidiary Ford Werke (of American parent Ford Company), brings richness to the accounting literature through re-centring people as the primary focus of accounting, recognising it as a social practice. Accounting has to "represent complex multidimensional constructs that are always limited and incomplete...encouraging a numerical view of reality" (Morgan 1988, p.480), and this serves to deny a voice for the excluded, or the 'Other' (Broadbent 1995; Funnell 1998). Therefore, the numbers produced by accounting at times require alternate 
A thanatopolitical visualisation of accounting history: Giorgio Agamben and Nazi Germany.

renderings, with other forms of accounts (re)presenting reality (Bay 2018, p.50). It was evident that accounting information alone, even if plentiful, cannot illustrate a loss of political bios, and so the critical approach of alternative accounting was attended to.

Alternative accounts are a way of talking back to the limited and sterile practice of accounting, by giving marginalised and suppressed 'Others' the opportunity to account for themselves (Tregidga 2017, Shearer 2002). These accounts form alternate renderings of accounting information, which produce new visibilities, or ways of knowing and understanding events (Dey et al 2010, p.64). This account can take many forms, and for this paper, oral histories in the form of testimonies were employed. Testimony, as an alternative account, is for Campbell (2011, p.41) "the privileged mode of a new genre to be called thanatopolitical writing". Hammond and Sikka (1996, p.10) argue that it "offers the opportunity to change the focus towards accounting's effects on people". These testimonies are unique, in that the victims of lost political bios, at least those who survived, were able to speak to their own experiences as slave and forced labourers, to give depth and understanding to what a loss of political bios meant, felt like, looked like, and what living with that legacy is like. For this, alternative accounts of those who worked for companies, as the instruments of State intervention in the lives of individuals, were sought. This data was difficult to source, but the business history of Ford Werke, unlike other business histories, concentrated on testimony as a means of 
A thanatopolitical visualisation of accounting history: Giorgio Agamben and Nazi Germany.

telling the story of Ford Werke's Nazi involvement and Holocaust collaboration. This unique dedication to (re)telling the business history through the testimony of victims of that company enabled a movement beyond the traditional confines of business documentation to create space for 'Others' to give account and narrate their loss of political bios on their own terms. It is for this purpose that Ford Werke was chosen. Given that there is a paucity of studies within the accounting literature highlighting the stages of persecution of Jewish and non-Aryans beyond extermination in death camps, the focus of the paper is primarily on these first two panels.

The triptych approach and the inclusion of a financial bios pays attention to calculative practices and the insidious nature of hiding, or masking, the loss of financial, political and eventually physical life. This paper reveals the power relations between the State, business and accounting under thanatopolitics. By focusing on the business sphere, which throughout the Holocaust was motivated primarily by profit, the infiltration of the private sphere reveals the consequences for people when accounting creates invisibilities.

\section{The theoretical triptych: Applying Agamben in Nazi Germany}

5.1 The first panel of the theoretical triptych: Loss of financial bios 
A thanatopolitical visualisation of accounting history: Giorgio Agamben and Nazi Germany.

Banks in Germany formed the epicentre of the economy. "Banks owned the majority of corporate stock, served on corporate boards, were involved with stock market speculation and had little concern with the interests of individual minority shareholders" (Harston 1993, p.5). Deutsche Bank, as one of the largest banks in Germany, administered accounts of other businesses and citizens by being "involved in shifts of assets and transfers of property" which inevitably led to complicity "in what amounted in practice to a large-scale purge of German economic life" (James 2001, p.5).

Deutsche Bank became an instrument for facilitating the loss of financial bios while adopting sinister means of redirecting the wealth of exterminated Jews back to the Reich. The 'administration' of bank accounts was major business for the Deutsche Bank, where "most of the true owners of this property were the murdered victims of the National Socialist genocide" (James 2001, p.171). Its role in fulfilling the State policy of Aryanisation was no doubt "a vital element in a chain of exploitation and theft" (James 2001, p.208), which deprived non-Aryans of their financial bios. Once depleted of economic resources and the social privileges those resources once provided, most nonAryans who had not escaped Nazi Germany were exposed to further exploitation and degradation. This panel of the triptych emphasises the notion that confiscation of wealth and "seizure of property acts as an important catalyst in accelerating the downward spiral across the threshold to genocide" (Dean 2008, p.15), leaving non- 
A thanatopolitical visualisation of accounting history: Giorgio Agamben and Nazi Germany.

Aryans vulnerable to further exercises of thanatopower. With reference to the Holocaust and in terms of the history of accounting, the loss of financial bios is played out in two ways: first, through the Aryanisation policies of the Nazis and the concomitant role of businesses, and second, erasure of financial bios exemplified by the silences in Deutsche Bank's annual report.

The first action to remove Jewish influence from Nazi Germany was to exclude the Jews from the German economy, a policy known as 'Aryanisation.' James (2001, p.212) outlines the rollout of Aryanisations by dividing the process into several phases:

In the first, from 1933 to 1937, there were no [explicit] State initiatives...to expropriate or eliminate Jewish-owned business [this stage was termed 'voluntary']. In the second, from 1937 to 1939, in Germany, the state aimed at the elimination of Jewish business life... In the third, from 1938 onward, the expropriation of Jewish property outside the former German territories took place in the context of a radical mobilisation of anti-Semitic resentment, and then of a racial war. The seizure of property in Austria and the Czech lands, and the immediate and brutal persecution of Jews, provided a precedent for later occupation strategy.

On 12 June 1933, the Law Against Betraying the German National Economy (1933) was introduced (Bajohr 2002, p.154). This left the Jewish population particularly vulnerable, giving power to the banks to freeze assets, investments and income, confiscate accounts receivable, and seize passports to ensure Jews could not escape without paying an emigration levy - the Reich Flight Tax (1931) (Bajohr 2002, p.157). Restrictions were imposed on the use of Jewish assets, which prevented Jews from owning businesses and 
A thanatopolitical visualisation of accounting history: Giorgio Agamben and Nazi Germany.

"the right to earn a living...the program effectively demanded the exclusion of Jews from economic life and their progressive expulsion from Germany" (Dean 2008, p.19).

After mass boycotts of Jewish businesses, called for by the State and its agencies, other laws were passed to curtail the economic life of the Jews. This included the Law for the Restoration of the Professional Civil Service (1933), which dismissed thousands of Jews from work when 'race' became a qualification for employment (Goldhagen 1996, p.91). Other sanctioned racist and discriminatory practices towards Jews included the Law on the Admission to the Legal Profession (1933), Law Against Overcrowding in Schools and Universities (1933), The Denaturalization Law (1933), The Law on Exchange Control (1935) The Army Law (1935) and the Nuremberg Laws (1935) (United States Holocaust Memorial Museum 2018). These laws were designed to physically remove Jews from the legal profession, from attending school or university, from receiving marriage loans, to revoke German citizenship and block bank accounts. In sum, they were implemented to progressively narrow the space the Jews could occupy in Nazi Germany.

By 1938, Aryanisation was in full effect through constricting legislation including The Decree against the Camouflage of Jewish Firms (1938), the Order for the Disclosure of Jewish Assets (1938), the Jewish Capital Levy (1938), the Decree on the Confiscation of Jewish Property (1938), which culminated in the Decree on the Exclusion of Jews from 
A thanatopolitical visualisation of accounting history: Giorgio Agamben and Nazi Germany.

German Economic Life (1938) (USHMM 2018). The Nazis had effectively reduced the Jewish people to poverty, casting them aside with no financial means to live, or to survive. Goldhagen (1996, p.137) explains that "the Germans' exclusion of Jews from the economy proceeded throughout the first years of the regime as the economic health of the country permitted, and then with increased vigour in 1938", with the first stages of death enabled through the policies of Aryanisation instrumentalised through businesses such as Deutsche Bank which explicitly targeted financial bios.

Deutsche Bank, in its role in fulfilling the State policy of Aryanisation, used of euphemism (Nazi-Deutsch rhetoric ${ }^{\text {vi }}$ ) to make Jewish economic extermination less visible. Accounting was altered to a form of Nazi-Deutsch, obscuring the human element of events and transactions. Transactions related to Aryanisations were subsumed under a Nazi-Deutsch account titled 'special items or one-off transactions' (Annual Report 1936, p.11; James 2001). Supplemental material for Deutsche Bank's 1938 Annual Report includes a 'breakdown of profits from transactions not regularly recurring,' described by James (2001, p.208) as pertaining to "special profits and brokerage fees in connection with Aryanisations, sales of securities and real estate, fees for listing on the stock exchange, trustees, mortgage brokerage etc". Apart from rare instances of particularly important or unusual cases, money procured from the devastation of Jewish 
A thanatopolitical visualisation of accounting history: Giorgio Agamben and Nazi Germany.

financial bios was placed into the 'special items or one-off transactions' account which obscured the details of the transaction, silencing:

the core element of the whole process of Aryanisation. Jews were pressed or forced to sell businesses that they would not otherwise, in the absence of a viciously persecuting regime, have sold. They did not want money that could be transferred out of Germany only with great difficulties, and further losses (by 1938-39 an emigrant owning financial assets would be required to leave ninety-eight to ninety-nine percent of these behind in Germany) (James 2001, pp.208209).

The human account of those impacted by the Aryanisations was silenced as it fell outside the predominant discourse of accounting.

Nazi-Deutsch was further utilised in their annual reports to disguise the removal of Jewish financial bios through an Aryanisation of the workforce, bolstered by the Law for the Restoration of the Professional Civil Service (1933); Law for the Protection of German Blood and German Honour (1935) and Reich Citizenship Law (1935). Deutsche Bank outlines, "we were able to make considerable new hires in the reporting year and fully replace the number of our employees who retired or who left our services for other reasons" (Annual Report 1935, p.18, emphasis added) and given the contextual and political pressures of the time, it is speculated as including the dismissal of workers on racial grounds that occurred in the same year. 
A thanatopolitical visualisation of accounting history: Giorgio Agamben and Nazi Germany.

In the absence of Nazi-Deutsch, Deutsche Bank simply remained silent on their role within Aryanisations. In examining Deutsche Bank's annual reports from 1933-1944, only one specifically mentions details surrounding an Aryanisation: "In Berlin we have taken over customers of the bank Mendelssohn \& Co. for our newly acquired business associates ..." (Annual Report 1938, p.8). The silence on any further details obscures several important things. First, that this 'take over' was in fact a forced Aryanisation of a Jewish-owned banking firm (James 2001). Second, that Deutsche Bank had an active role in this Aryanisation and was therefore complicit in denuding the Jewish owners of their financial bios, and third, that if the accounting had been made visible, it would likely have shown an acquisition far below its market value (Hayman 2009). These predatory Aryanisations gave little, or no, goodwill consideration for such purchases, and the ensuing financial distress of the Jews was compounded by extortionate taxes on their wealth. Ultimately, this left Jews with few options: to emigrate in poverty or remain in an increasingly hostile German Reich.

Further investigations into Aryanisations carried out by Deutsche Bank reveal that while some of the non-Aryans who had been stripped of financial bios managed to emigrate, albeit in a destitute state, others were placed into concentration camps and few survived (Hayman 2009; James 2001). Deutsche Bank, in close collaboration with the Nazis, identified Jewish businesses to Aryanise, took them over and discarded the 
A thanatopolitical visualisation of accounting history: Giorgio Agamben and Nazi Germany.

financial livelihoods of the former owners. Increasingly, Deutsche Bank became wedded to the Nazi party, employing party members and displaying the swastika on official company documents (Annual Report 1939). Deutsche Bank's accounting for Aryanisations, particularly the 'special items or one-off transactions' account, mystified the actual nature of the events as they impacted humans, further silencing "the intrinsic value of the people's lives that [were] being destroyed" (Chwastiak and Lehman 2008, p.321) and its role in the instrumentalisation of Nazi thanatopolitical ideology. This rendered the human ramifications invisible, as lost financial bios provided the catalyst for further losses of life, both political and existential.

\subsection{The second panel of the theoretical triptych: loss of political bios}

Many of the distinctive legislative instruments designed to rid the Jews of their financial bios similarly facilitated the removal of their political bios. The series of laws designed to remove Jews from the economy, and from Nazi Germany itself, served also to alienate and inhibit liberty. The revocation of political bios facilitated by the Nuremberg Laws (1935) ensured "life and death [were] not properly scientific concepts but rather political concepts" (Agamben 1995, p.164). Without financial means and civil rights, Jews and other 'undesirables' either emigrated under duress, or were forcibly placed into a range of camps and used as slave or forced labour (Newton 1990, pp.366367). Minister Goebbels recorded in his diary in 1942 that "the procedure is a pretty 
A thanatopolitical visualisation of accounting history: Giorgio Agamben and Nazi Germany.

barbaric one...not much will remain of the Jews....it can be said that about $60 \%$ of them will have to be liquidated whereas only about $40 \%$ can be used for forced labour" (cited in Ferencz 2009, p.18). It was evident that at the outset, the Jews were only allowed a stay of execution based on their productive capacity, further detailed by instructions from Auschwitz's Commander Höss:

the whole Jewish question will be solved in general for all of Europe after the war at the latest...Jewish manpower is to be used for heavy manual labour...Care is to be taken that Jewish labour is used only in productions which will suffer no noticeable interruption in case of a rapid withdrawal of these labour forces...It is to be avoided in every case that Jewish workers become indispensable in essential production... (cited in Ferencz 2009, p.13).

Depicted only partially through accounting representations, the loss of financial bios established the conditions for complete exploitation by profit-driven companies such as Ford Werke, leading to a loss of political bios.

Ford Werke became indispensable to the Nazi war effort. For example, the Blitzkrieg that nearly secured the European continent for Nazi Germany between September 1939 and December 1941 was made possible by Ford Werke military vehicles (Billstein et al. 2000). Despite maintaining close ties to its American parent, Billstein et al. (2000, p.158) note, "during the twelve years of the 'Thousand Year Reich', [it] took every effort to look and act like a loyal German company". 
A thanatopolitical visualisation of accounting history: Giorgio Agamben and Nazi Germany.

The outbreak of war precipitated constant and severe labour shortages in Nazi Germany. This shortage was met by involuntary labour, such as that of Yvon Thibaut from Belgium, who was compelled to perform forced labour at Ford Werke at 18 years old. He testifies:

I was drafted to go to Germany as a forced labourer. They told me there that if I didn't go, my father or my brother would have to go in my place. Because I didn't want that, I went to Germany, to work there...On 28 October 1942 I was transported from the train station in Charleroi. There I had to sign papers that I was going voluntarily. Of course! (Billstein et al. 2000, pp.182-184).

Ford Werke was one of many companies that made use of 7.6 million foreign labourers, as well as prisoner of war (POW) labour, in direct contravention of the 1929 Geneva Convention. In addition, Ford Werke made use of slave labour from Buchenwald concentration camp, where the program of extermination-through-labour was practiced within the state of exception (Billstein et al. 2000). Workers were differentiated into racial categories as mandated by the State, which dictated the wage rate, conditions, food supplied and work to be performed. The wage rate was between 6.5-8 RM for German workers, 4 RM for foreign workers and 3 RM for Jewish workers per day (Bureau of Labor Statistics 2002; Hayes 2004, p.256), acknowledging that Jewish labour "could not be as productive as a free, normal, well-fed German worker; thus, it was estimated...that a seventy-five percent efficiency was all that could be expected" (Hayes 1987, p.117). These wages paid for transportation, food, and clothing costs, 
where Ford Werke was able to make "use of a large leeway to deduct for food and lodging. The payroll accountant at Ford Werke testified, soon after the war, that after withdrawals for taxes, insurance, lodging and food the [POWs] received less than half the wages due them under the regulations" (Billstein et al. 2000, p.154). Beyond wages, accounting for slave and forced labourers is restricted to mere enumerations of employees, listed by gender and work performed. The profit seeking of Ford Werke, enabled through the alteration of accounts, prevailed over the care of its workers, while concurrently supporting thanatopolitical imperatives towards the death of the Jews and other prisoners. Funnell $(1998$, p.452) explains that the value of Jewish labour was converted to a "one-dimensional metric, an integer as a component of tabulations that could be arithmetically manipulated, [that] stripped the identity and all other qualities from the Jews... [and avoided] divulging the human correspondence of their accounts. The Jew was recognised no longer as a social being".

Inhumane treatment of forced labourers was encouraged by the Nazis, in accordance with State-directed thanatopolitical racial hierarchies, to separate the racial pedigree between foreigners. Thus, the financial racism predicated on the Nazi iteration of modern racism and legislated as part of Aryanisation policies, played out into a political divide between foreign, Jewish, POW and other labourers. Kamila Felinska, a Polish national mistaken firstly for a Russian forced labourer and then for a French 
A thanatopolitical visualisation of accounting history: Giorgio Agamben and Nazi Germany.

woman, recollected the differences between the Ford Werke camps that housed Russians and those that housed the French as:

like heaven and earth, that was a completely different life, we even got to dance in the evenings, there was coffee... It was that way because the French were getting Red Cross packages. The food was better there...We had one-hour lunch break...We got fifty marks a month at Ford... In the Russian camp we got nothing (Billstein et al. 2000, p.193).

Of all the degrading and horrific experiences of the forced labourers at Ford Werke, the most common survivor memory relates to the de-individualization and dehumanisation accorded through identification by number. Stripping people of their individuality and sense of self through legal instruments and Nazi thanatopolitical actions designed to make the humanness of the 'Other' invisible through numerical representation brutalised the human experience. When not viewed as humans, they were not treated as such, leading to acts of violence and exposure to death(s). Accounting contributed to the removal of political bios on an individual, naming level by reducing all problems (people) to numbers, where the intrinsic worth of the victims were lost. The calculative nature of accounting drained "from the objects of its calculations features which were not amendable to measurement and reporting in a numerical format" (Funnell 1998, pp.458-459). The numbers suppressed the people, their uniqueness and their worth, exemplified in the alternative accounts of the survivors of Ford Werke's factories: 
... we got numbers. We had a sign with a card, they hung that around our necks, where we were all naked, and that was your entry number as a prisoner in Buchenwald. I had number 481756. You had to be able to read that in German and remember it, because constantly, when you were in the camp, later, you might be called for any reason, they called us by number, never by name... (Yvon Thibaut in Billstein et al. 2000, pp.209-210).

When we first arrived with the transport, during the roll call my number was called: 465 , and I didn't understand. No family, nothing, I had only had the number. Prisoner numbers, ah I took many blows for that... (Kazimierz Tarnawski, in Billstein et al. 2000, pp.186-187).

[What number did you have? - Interviewer] 456. They had all the numbers listed at the guardhouse. The policeman came, he would call a number, never the first or last name. As though he was calling your name. Maybe it was on a list somewhere, the name, where I come from and so on. But in the camp no names were used...I had begun to piss in my pants, I was completely neglecting myself (cries) (Stepan Saiko in Billstein et al. 2000, p.171).

After fifty years everything is smoothed out, and hunger, beatings and injuries are forgotten, but it will always remain in memory that I was not Kulagina Inna, but No. 987 - Inna Kulagina, forced labourer for Ford Werke (Inna Kulagina in Billstein et al. 2000, p.228)

It is clear from the testimonial accounts that the workers felt, in the local, time-specific context of slave labour, and at the time of their interview, that one of the most enduring violations of the war was dehumanisation and the assignation of numbers as identification to conceal personal identity.

Ford Werke profited from both the war and the competitive advantage stemming from the forced labour used from 1940 to 1944, so much so that when a highlevel tax inspector was sent in September 1943 to audit Ford Werke: 
...he observed an impressive growth in assets at all of the companies. He found that [Ford Werke] assets had grown from 14.8 million RM in 1938 to 36.7 million RM in 1942, and that net liquid assets had in the same period risen from 10 million RM to 28 million RM. [He] attributed this phenomenal growth [to] the use of cheap labour, such as prisoners of war and 'Ostarbeiter' [Eastern European forced labourers] (Billstein et al. 2000, p.154).

It is interesting to note that despite profiting significantly from the Nazi war effort and maintaining a 'Nazi German' face throughout the war, "as soon as the US troops arrived, [Ford Werke] turned into the courageous protectors of American property" (Billstein et al. 2000, p.158). This shielded Ford Company and Ford Werke from the fate of other Nazi companies criminally tried at Nuremberg. It was not until the 1990s, when survivors of the Holocaust sought restitution for forced and slave labour, that Ford Werke was questioned about its role during the war.

From this illustration, an appreciation of the precarious nature of personal freedom and political life in instances where States implement a state of exception can be formed. The ideal of human rights "always simultaneously prepare[s] a tacit but increasing inscription of individuals' lives within the $[\mathrm{S}]$ tate order, thus offering a new and more dreadful foundation for the very power from which they [want] to liberate themselves" (Agamben 1995, p.121). Lost political bios facilitated dehumanisation which enabled inhumane treatment, for which Lippmann (2009, p.76) blames 
accountants, as "their reports hid the human dimension of what occurred". Accounting practices were therefore intermediaries to the loss of financial and political bios, but also the ensuing genocide, "as the accounting information disregarded basic human rights of the laborers" (Lippman and Wilson 2007, p.298), experiences which have been reinstated through alternative accounts. Once liberty, freedom and rights were stripped away, either by law or by the threat of violence, the possibilities for inhumanity became endless. The next goal of the thanatopolitical State was extermination of Jewish and non-Aryan zoē.

\subsection{The third panel in the theoretical triptych: Loss of zoē}

The final panel in the triptych relates to the loss of life experienced by over six million people during the Holocaust. This loss was effected in a number of ways: poisoning in the gas chambers, execution through firing squads, starvation, death as a result of harsh conditions in the camps, death through labour, and violence meted out as punishment or even amusement by guards. Those who were killed at the death centres of the Nazi apparatus were not exterminated "in a mad and giant holocaust but exactly as Hitler had announced, 'as lice,' which is to say, as bare life" (Agamben 1995, p.114), possible due to the prior removal of their financial and political bios. The sacrosanct parts of humanity (encapsulated by zoē) became politicised and exposed to State control. Once conferred rights are revoked through legislation and the state of 
A thanatopolitical visualisation of accounting history: Giorgio Agamben and Nazi Germany.

exception legalised, zoē enters the political and legal sphere in ways that were not possible before the dehumanisation took place.

As was the case with Aryanisation and slave/forced labour practices, business decisions became life and death decisions. Accountants, for example, "used a costbenefit analysis to compare the cost of killing children with gas and then burning their bodies, to the alternative of burning the children to death" (Lippman \& Wilson 2007, pp.288-289). 10 cents per child could be saved by the State in not gassing the children first (Fleischner 1977). Mass gassings were devised as efficiency measures implemented to deal with the genocide "in a manner similar to production in a factory, [that is]...killing based on the detailed organisation and principle of the assembly line" (Funnell 1998, p.453). German pharmaceutical companies, such as Degussa and IG Farben (through their joint venture Degesch), produced the gas Zyklon B that was used directly in this assembly line of death (Hayes 2004; Twyford 2018). Despite this fact, corporate officials denied knowledge of the use of the gas, noting that their job was to supply the Nazis "as far as output and the allocations of the Working Committee allowed, and what the Black Corps did with the substance was none of their business" (Hayes 2004, p.294).

The extermination of Jews was borne from the lawlessness in the state of exception, which exposed non-Aryans and other 'undesirables' to unfettered violence, culminating in death. German Reich law passed over into thanatopower, which provided 
A thanatopolitical visualisation of accounting history: Giorgio Agamben and Nazi Germany.

legal means to remove the financial and political bios of those who had previously been legitimate members of the citizenry. As zoē, the physical death of these non-citizens was just a matter of time.

\section{Conclusion}

Thanatopolitical State imperatives facilitated by a complex matrix of interrelated actors and practices has had horrific consequences for individuals. The defining condition that allowed for the operation of thanatopower and the pursuit of death in various forms was the suspension of civil rights in conjunction with supreme executive power - the enactment of the state of exception (Agamben 2005). Within the broader socio-political and legal context, accounting has largely escaped implication for its peripheral, yet integral, role in suppressing citizen loss of life. The utility of Agamben's thanatopolitical theory has been depicted, which to reiterate provides new understandings and renders visible that which was previously concealed by practices such as accounting by examining the silences in accounts, and utilising subjects' testimony as alternative accounts.

This paper extended Agamben's conceptualisations to include the notion of financial bios and demarcate the difference between a political and financial life. How calculative practices are implicated in the violent machinations of State/citizen relations 
A thanatopolitical visualisation of accounting history: Giorgio Agamben and Nazi Germany.

has also been exposed, with particular attention given to the silences in the accounting records. The triptych has revealed how the Aryanisation policy stripped non-Aryans of financial bios as a necessary first step in the eventual genocide. The loss of financial bios illustrated how a mere record can have devastating effects, as it ignores the ways in which lives were (re)presented within it. Deutsche Bank became a conduit for State policy, which stripped citizens of their wealth and left them exposed to destitution, violence and death. From this vulnerable position, the stage was set for people to experience further losses, political and existential.

The second panel of the triptych reinstated the lived human experience through testimony as a form of thanatopolitical writing, and illustrated how non-Aryans were exploited by companies such as Ford Werke, who were willing conspirators in the destruction of political bios. This destruction is masked through quantification, and the use of a range of alternative accounts have revealed this loss. The third and final panel in the theoretical triptych saw corporate complicity enable the mass murder of over six million Jews, with Zyklon B production helping to fulfil the thanatopolitical imperative to make die the zoē with impunity (Hayes 2004; Agamben 1995, 2005).

The power apparatuses that enabled the Holocaust, including accounting and business, were instrumental in implementing and disguising the losses initiated by the state of exception, as demonstrated through the theoretical triptych. Accounting as a 
social practice primes organisational systems, human behaviour and political action, which directly impacts the lives of people. The mobilisation of accounting during totalitarian regimes, or in the pursuit of thanatopolitics, can mystify death in its financial, political, and actual forms by using one-dimensional integers to mask the amorality of such action. While the utility of this theoretical device is demonstrated with reference to the Holocaust, this paper argues that it is relevant for the examination of accounting in other historical and contemporary instances of thanatopolitics and the rise of 'undesirable' non-citizens, including the refugee/detainee/illegal/immigrant/infectious.

Other states of exception including war, political turmoil, natural disasters and even pandemics, are of increasing concern, requiring a new set of theoretical 'tools' with which to recognise the implications of accounting. Agamben gives us the tools we need for furthering our understanding of accounting in thanatopolitical States, and there remains significant scope for the application of this theoretical triptych in future research. For example, ICE (United States Immigration and Customs Enforcement) raids on immigrant workplaces following 'employee audits' and the perusal of accounting information (including utilities bills and credit data) have curtailed the ability of those citizens to work and earn a meagre living (loss of financial bios). This has progressed for some to the point of internment in detention facilities, where their basic human rights are disregarded (loss of political bios). Similarly, asylum seekers fleeing war and 
A thanatopolitical visualisation of accounting history: Giorgio Agamben and Nazi Germany.

persecution pay exorbitant fees to people smugglers (loss of financial bios) to be denied asylum and instead imprisoned in corporate-run detention centres indefinitely, reduced to a 'cost' of border security that hides the human dimension of events (loss of political bios). Whilst these examples do not ostensibly progress to the third panel and the loss of zoe, the loss of political and financial bios places people in vulnerable and hopeless situations which can lead to self-harm and suicide.

Other future research endeavours could add to the literature on accounting and the Holocaust by investigating other German companies and their complicity with the Nazi State, such as Degussa, I.G. Farben, BMW or Bahlsen. Other contexts, including historical totalitarian States such as fascist Italy, communist U.S.S.R, China, and Kampuchea, socialist Burma, or even contemporary camps run by so-called democratic States such as the United States (Guantanamo Bay) and Australia (Nauru and Manus Island detention centres), are suggestions for future research. The diverse range of accounting histories can be supplemented by narratives as shaped by this theoretical structure and a thanatopolitical visualisation of history, which enhances our understanding, and the impact, of accounting as a practice that can silence, disguise or hide the lived human experience. 


\section{References}

Adams D and Erevelles N (2017) Unexpected spaces of confinement: Aversive technologies, intellectual disability, and 'bare life'. Punishment and Society 19(3): 348-365.

Agamben G (1995) Homo Sacer: Sovereign power and bare life. Stanford, Stanford University Press.

Agamben G (2002) Remnants of Auschwitz: The witness and the archive. Brooklyn, Zone Books.

Agamben G (2005) State of Exception. Chicago, The University of Chicago Press.

Alawattage C, Graham C and Wickramasinghe D (2018) Micro-accountability and biopolitics: Microfinance in a Sri Lankan village. Accounting, Organizations and Society 72: 38-60.

Amernic J and Craig R (2017) CEO speeches and safety culture: British Petroleum before the Deepwater Horizon disaster. Critical Perspectives on Accounting 47: 61-80.

Andrew J (1999) Reconsidering nature and accountability: the possibilities of strategic postmodernism. PhD thesis. Department of Accounting and Finance, University of Wollongong. Retrieved 05/06/2018 $<$ http://ro.uow.edu.au/theses/1025>

Anti-Semitic Legislation 1933-1939 (2018) United States Holocaust Memorial Museum, retrieved 31/05/2018, $<$ https://www.ushmm.org/wlc/en/article.php?Moduleld=10007901 2018>.

Arad Y, Gutman Y and Margarliot A (1981) Documents on the Holocaust: Selected Sources on the Destruction of the European Jewry. Jerusalem, Yad Vashem.

Arendt H (1964) Labor, Work, Action. Christianity and Economic Man: Moral Decisions in an Affluent Society Conference, November 10, University of Chicago

Arendt H (1973) The perplexities of the rights of man, in Campbell T and Sitze A (eds.) (2013) Biopolitics: A reader. Duke University Press, Durham.

Arrington C and Francis J (1993) Giving economic accounts: Accounting as cultural practice. Accounting, Organizations and Society, 18(2/3): 107-124.

Bajohr F (2002) 'Aryanisation' in Hamburg: The economic exclusion of Jews and the confiscation of their property in Nazi Germany. New York, Berghahn Books.

Bauman Z (2001) Modernity and the Holocaust. New York, Cornell University Press.

Bay C (2018) Makeover accounting: Investigating the meaning-making practices of financial accounts. Accounting, Organizations and Society 64: 44-54.

Bazzicalupo L (2006) The ambivalences of Biopolitics. Diacritics 36(2): 109-116.

Benjamin W (1942) On the concept of history in Eiland $\mathrm{H}$ and Jennings M Selected Writings 1938-1940. 1(2)

Cambridge, Harvard University Press.

Bhimani A (1994) Accounting and the Emergence of 'Economic Man'. Accounting, Organizations and Society 19(8): 637-674.

Bigoni M and Funnell W (2015) Ancestors of governmentality: Accounting and pastoral power in the $15^{\text {th }}$ century. Critical Perspectives on Accounting 27: 160-176.

Billstein R, Fings K, Kugler A and Levis N (2000) Working for the Enemy: Ford, General Motors, and Forced Labour in Germany during the Second World War. New York, Berghahn Books.

Black E (2001) IBM and the Holocaust. New York, Crown Publishers.

Booth C, Clark P, Delahye A, Procter S and Rowlinson M (2007) Accounting for the dark side of corporate history: Organizational culture perspectives and the Bertelsmann case. Critical Perspectives on Accounting 18: 625-644.

Broadbent J (1995) The Values of Accounting and Education: Some Implications of the Creation of Visibilities and Invisibilities in Schools. Advances in Public Interest Accounting 6: 69-98.

Browning C (1980) The Government Experts in Friedlander H and Milton S (eds) (1980). The Holocaust: Ideology, Bureaucracy and Genocide. Millwood, Kraus International Publications.

Bullock A (1952) Hitler: A Study in Tyranny. New York, Harper Perennial.

Burchell S, Clubb C and Hopwood A (1985) Accounting in its social context: Towards a history of value added in the United Kingdom. Accounting, Organizations and Society 10(4): 381-413.

Campbell T (2011) Improper Life: Technology and biopolitics from Heidegger to Agamben. Minneapolis, University of Minnesota Press. 
Chwastiak M and Lehman G (2008) Accounting for war. Accounting Forum 32(4): 313-326.

Cinquini $L$ (2007) Fascist Corporative Economy and Accounting in Italy during the Thirties: Exploring the Relations between a Totalitarian Ideology and Business Studies. Accounting, Business \& Financial History 17(2): 209-240.

Cooper C (2015) Entrepreneurs of the self: The development of management control since 1976. Accounting, Organizations and Society 47: 14-24.

Cooper C, Graham C and Himick D (2016) Social impact bonds: The securitization of the homeless. Accounting, Organizations and Society 55: 63-82.

Dean M (2008) Robbing the Jews. New York, Cambridge University Press.

Deleuze G (1992) Postscript on the societies of control. October 59(Winter): 3-7.

Detzen D and Hoffmann S (2020) Accounting and ideology: The case of a German university under the Nazi regime. Accounting History 25(2): 174-192.

Deutsche Bank (1935) Annual Report 1935

Deutsche Bank (1936) Annual Report 1936

Deutsche Bank (1938) Annual Report 1938

Deutsche Bank (1939) Annual Report 1939

Dey C, Russell S and Thomson I (2010) Exploring the potential of shadow accounts in problematizing institutional conduct in Ball A and Osborne $\mathrm{S}$ (eds.). Social accounting and public management: Accountability for the common good, pp.64-75. New York, Routledge.

Dillard J (2003) Professional Services, IBM, and the Holocaust. Journal of Information Systems 17(2): 1-16.

Erlenbusch V (2013) The place of sovereignty: Mapping power with Agamben, Butler and Foucault. Critical Horizons 14(1): 44-69.

Esposito R (2013) Biopolitics, in Campbell T and Sitze A (eds.) Biopolitics: A reader. Duke University Press, Durham.

Ferencz B (1979) Less Than Slaves: Jewish forced labour and the quest for compensation. Indiana, Indiana University Press.

Fleischman R and Radcliffe V (2005) The roaring nineties: Accounting history comes of age. Accounting Historians Journal 32(1): 61-109.

Fleischner E (ed.) (1977) Auschwitz: Beginning of a New Era. New York, Cathedral Church of St John the Divine. Fogel C (2014) On Privileged Grounds: Sport, Law, and Agamben's State of Exception. Journal of Politics and Law 7(3): 74-78.

Fontana A (1999) Du droit de résistance au devoir d'insurrection in Zancarini J (ed.) Lé droit de résistance. Paris, EN.

Foucault M (1976-2003 ed.) Society Must Be Defended: Lectures at the Collège de France 1975-1976. New York, Picador.

Foucault M (1978) The History of Sexuality: Volume I: An introduction. New York, Vintage Books.

Foucault M (1979-2008 ed.) The Birth of Biopolitics: Lectures at the Collège de France 1978-1979. New York, Picador.

Funnell W (1998) Accounting in the Service of the Holocaust. Critical Perspectives on Accounting, 8(4): 435-464. Genel K (2006) The question of biopower: Foucault and Agamben. Rethinking Marxism, 18(1):43-62. Giddens A (1987) Social theory and modern sociology. Cambridge, Polity Press.

Goldhagen D (1996) Hitler's Willing Executioners: Ordinary Germans and the Holocaust. London, Abacus. Gray N and Porter L (2015) By any means necessary: urban regeneration and the 'state of exception' in Glasgow's Commonwealth Games 2014. Antipode 47(2): 380-400.

Grunberger R (1971) The 12-Year Reich: A social history of Nazi Germany 1933-1945. Canada, Hold, Rinehart and Winston, Canada.

Hamburg Foundation for Social History (ed.) (1987) Das Daimler-Benz-Buch: Ein Rustungskonzern im Tausendjahrigen Reich. Hamburg, Delphi Politik published by GRENO.

Hammond T and Sikka P (1996) Radicalizing accounting history: the potential of oral history. Accounting, Auditing \& Accountability Journal 9(3): 79-97. 
Harston M (1993) The German accounting profession - 1931 and before: A reflection of national ideologies. The Accounting Historians Journal 20(2): 139-162

Hayes P (1987) Industry and ideology: IG Farben in the Nazi era. New York, Cambridge University Press. Hayes P (2004) From Cooperation to Complicity: Degussa in the Third Reich. New York, Cambridge University Press.

Hilberg R (1983) The Destruction of the European Jews. New York, Holmes and Meir.

Himick D (2016) Actuarialism as biopolitical and disciplinary technique. Accounting, Organizations and Society 54: 22-44.

Hopwood A (1984) Accounting and the Pursuit of Efficiency in Hopwood A and Tomkins C (eds.) Issues in Public Sector Accounting. Oxford, Philip Allan.

Hopwood A (1986) Management Accounting and Organizational Action: An Introduction in Bromwich M and Hopwood A (eds.) Research and Current Issues in Management Accounting, London, Pitman.

Howell A and Richter-Montpetit M (2019) Racism in Foucauldian security studies: Biopolitics, liberal war, and the whitewashing of colonial and radical violence, International Political Sociology 13(1): 2-19.

Huber C and Scheytt T (2013) The dispositif of risk management: Reconstructing risk management after the financial crisis. Management Accounting Research 24(2): 88-99.

Humphreys S (2006) Legalizing Lawlessness: On Giorgio Agamben's State of Exception. The European Journal of International Law 17(3): 677-687.

James H (2001) The Deutsche Bank and the Nazi Economic War Against the Jews. Cambridge, Cambridge University Press.

James H (2012) Krupp: A History of the Legendary German Firm. Princeton, Princeton University Press. Kogon E (2006) The theory and practice of hell: The German concentration camps and the system behind them. New York, Farrar, Straus and Giroux.

LaCapra D (2007) Approaching Limit Events: Siting Agamben in Calarco M and DeCaroli S (eds.) Giorgio Agamben: Sovereignty and Life. Stanford, Stanford University Press.

Lavoie D (1987) The accounting of interpretations and the interpretation of accounts: The communicative function of 'the language of business'. Accounting, Organizations and Society 12(6): 579-604.

Lippman E (2009) Accountant's responsibility for the information they report: An historical case study of financial information. Accounting Historians Journal 26(1): 61-79

Lippman E and Wilson P (2007) The culpability of accounting in perpetuating the Holocaust. Accounting History 12(3): 283-303.

Llewelyn S (2003) What counts as 'theory' in qualitative management and accounting research? Introducing five levels of theorising. Accounting, Auditing \& Accountability Journal 16(4): 662-708.

Lueck K, Due C and Augoustinos M (2015) Neoliberalism and nationalism: Representations of asylum seekers in the Australian mainstream news media. Discourse \& Society 26(5): 608-629.

Maran L, Bracci E and Funnell W (2016) Accounting and the management of power: Napoleon's occupation of the commune of Ferrara (1796-1799). Critical Perspectives on Accounting 34: 60-78.

Marti I and Fernandez P (2013) The institutional work of oppression and resistance: learning from the Holocaust. Organization Studies 34(8): 1195-1223.

Martins R (2002) The Financialization of daily life. Temple University Press Philadelphia.

Martinez D (2011) Beyond disciplinary enclosures: Management control in the society of control. Critical Perspectives on Accounting 22(2): 200-211.

Matz A (1938) The position of the German accountant. Accounting Review 13(4): 392-395.

Mayer M (1997) Ein Ausnahmezustand auf Dauer: Giorgio Agamben über die Idee einer 'Biopolitik'. Berliner Zeitung 17 January: 21.

McGovern M (2011) The dilemma of democracy: Collusion and the state of exception. Studies in Social Justice 5(2): 213-230.

McLoughlin D (2016) The fiction of sovereignty and the real state of exception: Giorgio Agamben's critique of Carl Schmitt. Law, Culture and the Humanities 12(3): 509-528.

Hayman, S (director) (2009) Mendelssohn, the Nazis, and Me Motion picture, Renegade Pictures. 
Miller P (1986) Accounting for progress - national accounting and planning in France: A review essay. Accounting, Organizations and Society 11(1): 83-104.

Miller P (1990) On the interrelations between accounting and the State. Accounting, Organizations and Society 15(4): 315-338.

Miller P and O'Leary T (1987) Accounting and the construction of the governable person. Accounting, Organizations and Society 12(3): 235-265.

Miller P and Rose N (1990) Governing economic life. Economy and Society 19(1): 1-31.

Mishra P (2016) Welcome to the age of anger. The Guardian, 8 December. Available at:

https://www.theguardian.com/politics/2016/dec/08/welcome-age-anger-brexit-trump (accessed 9 March 2020).

Mommsen H (1996) Das Volkswagenwerk und seine Arbeiter im Dritten Reich. Düsseldorf, Econ.

Morgan G (1988) Accounting as reality construction: Towards a new epistemology for accounting practice. Accounting, Organizations and Society 13(5): 477-485.

Neu D (2000) 'Presents for the “Indians': Land, colonialism and accounting in Canada. Accounting,

Organizations and Society 25(2): 163-184.

Newton D (1990) Germany 1918-1945: From days of hope to years of horror. Melbourne, Collins Dove.

Passavant P (2007) The contradictory state of Giorgio Agamben Political Theory 35(2): 147-174.

Peukert D (1982) Inside Nazi Germany: Conformity, Opposition, and Racism in Everyday Life. New Haven, Yale University Press.

Quattrone P (2006) The possibility of testimony. Organization 13(1): 143-157

Rigi J (2012) The corrupt state of exception: Agamben in the light of Putin. Social Analysis 56(3): 69-88.

Roethlisberger F and Dickson W (1939) Management and the Worker. Cambridge, Harvard University Press.

Sargiacomo M (2015) Earthquakes, exceptional government and society. Accounting, Organizations and Society 42: 67-89.

Sargiacomo M, lanni L, D'Andreamatteo A, and D'Amico L (2016) Accounting and the government of the agricultural economy: Arrigo Serpieri and the Reclamation Consortia. Accounting History Review 26(3): $307-$ 331.

Shearer T (2002) Ethics and accountability: From the for-itself to the for-the-other. Accounting, Organizations and Society 27(6): 541-573.

Snoek A and Fry C (2015) Lessons in biopolitics and agency: Agamben on addiction. New Bioethics 21(2): 128 141.

Stokes P and Gabriel Y (2010) Engaging with genocide: the challenge for organization and management studies. Organization 17(4): 461-480.

Thorne K (2009) Will the people united in cyberspace never be defeated? Reflections on the global multitude in the epoch of American Empire. Critical Perspectives on Accounting 20(2): 255-266.

Tregidga H(2017) 'Speaking Truth to Power': Analysing shadow reporting as a form of shadow accounting. Accounting, Auditing and Accountability Journal 30(3): 510-533.

Twyford, E (2018) The State in pursuit of thanatopolitics: Accounting and the citizenry. Doctor of Philosophy thesis, School of Accounting, Economics and Finance, University of Wollongong,

https://ro.uow.edu.au/theses1/569.

United States Bureau of Labor Statistics, 'Prices and Wages by Decade: 1940-1949', accessed 23/11/2020, https://libraryguides.missouri.edu/pricesandwages/1940-1949

Vollmer $\mathrm{H}$ (2007) How to do more with numbers. Elementary stakes, framing, keying, and the three-

dimensional character of numerical signs. Accounting, Organizations and Society 32: 577-600

Walker, S 2000, 'Encounters with Nazism: British accountants and the Fifth International Congress on Accounting', Critical Perspectives on Accounting, vol. 11, pp.215-245.

Xenofontos S (2016) Agamben's State of Exception in Context: A Critical Analysis with Regard to Post-9/11 Jurisprudence. Legal Issues Journal 4(1): 113-128. 


\section{Appendix - List of persecutory legislation}

Reich Flight Tax (1931)

Reichstag Fire Decree (1933)

Enabling Act (1933)

Law Against Malicious Gossip (1933)

Law Against Betraying the German National Economy (1933)

Law for the Restoration of the Professional Civil Service (1933)

Law on the Admission to the Legal Profession (1933)

Law Against Overcrowding in Schools and Universities (1933)

Law for the Prevention of Progeny of the Genetically Unhealthy (1933)

The Denaturalization Law (1933)

Law for the Prevention of Hereditarily Diseased Offspring (1933)

The Law on Exchange Control (1935)

The Army Law (1935)

Law for the Protection of German Blood and German Honour (1935) (Nuremberg law)

Reich Citizenship Law (1935) (Nuremberg law)

Hitler Youth Law (1936)

Executive Order on the Reich Tax Law (1936)

Executive Order on the Law on the Alteration of Family and Personal Names (1938)

The Decree against the Camouflage of Jewish Firms (1938)

Order for the Disclosure of Jewish Assets (1938)

Jewish Capital Levy (1938)

Decree on the Confiscation of Jewish Property (1938)

Decree on the Exclusion of Jews from German Economic Life (1938)

Ordinance on the Restoration of Street Scenery at Jewish Commercial Centres (1938)

Ordinance on the Registration of the Property of Jews (1938)

Ordinance on an Expiation Payments by Jews of German Citizenship (1938)

The Decree Concerning the Surrender of Precious Metals and Stones in Jewish Possession (1939)

Excess Profits Act (1939) 
Decree of the Führer and Reich Chancellor on the Utilisation of the Requisitioned Property of Enemies of the Reich (1941)

Eleventh Ordinance of the Reich Citizen's Law (1942)

Audit of Dejewification Transactions (1942)

\section{Endnotes}

i Forced labour refers to labour carried out by foreigners that was generally in exchange for payment. Slave labour refers to labour carried out by Jews and other non-Aryan Germans that was paid not to the labourers, but to the State in a 'lease' agreement.

ii For example, when most citizens ask 'What do you do?' they are seeking an answer given in economic terms - i.e. what job/labour do you partake in; or 'Where do you live?' which gives socio-economic connotations.

iii Aristotle was the first to denote the zoe and bios ('active' life), an aspirational life which was purely political, without economic connotations.

iv A state of exception was declared during the financial crises in Germany in 1923 and France in 1925, 1935 and 1937, during union strikes and social upheaval in Britain in 1920, earthquakes in Italy in 1908, and by Presidents Lincoln - to provide a basis for the abolition of slavery in 1862 - and Roosevelt, to ensure passage of the New Deal in 1933 (Humphreys 2006, pp.679-680).

${ }^{\vee}$ A policy aimed to ensure that Nazi Germany became completely self-sufficient economically.

vi Nazi-Deutsch is the style of German language used during the Nazi period to euphemistically disguise the true meaning of words or phrases, for example 'selection' meant transfer to the death camps. 